\title{
Investigating EFL Learners' Readiness of Using Smartphone and Problems for Learning Oral English Communication Skills at Tertiary Level in an EFL Context
}

\author{
https://doi.org/10.3991/ijim.v14i14.14759 \\ Prodhan Mahbub Ibna Seraj ${ }^{(凶)}$, Hadina Habil \\ Universiti Teknologi Malaysia, Johor, Malyasia \\ mahbubegraduate. utm. my \\ Md. Kamrul Hasan \\ United International University, Dhaka, Bangladesh
}

\begin{abstract}
Although extensive research has been carried out to investigate EFL learners' readiness of using smartphone and problems in global EFL contexts, there remains a scarcity of evidence on EFL learners' readiness of using smartphone and problems faced for learning oral English communication skills at tertiary level in Bangladesh. The present study was conducted to explore Bangladeshi tertiary level learners' readiness of using smartphone and problems for learning oral English communication skills. This study employed a mixedmethod design, using a survey questionnaire and semi-structured interview as data collection instruments. The participants of this study were sixty-one learners (35 females and 26 males) who were studying at the department of English of a university. The findings from the questionnaire illustrated that EFL learners' level of readiness of using a smartphone was high, and the frequent problems they faced were lack of authentic materials, audio-video aids, oral practice environment, large size class and existing teaching method. Subsequently, from the findings of semi-structured interview solicited three themes regarding EFL learners' readiness were availability, usability and positivity for the use of smartphone and four themes regarding EFL learners' problems, such as psychological, linguistic, teachers' efficacy and use of mother tongue for learning oral English communication skills.
\end{abstract}

Keywords-Oral English communication skills, Learners' problems, Learners' readiness, Features of smartphones, English as a foreign language.

\section{Introduction}

Oral English communication skills (OECSs) which is one of the language skills, is very crucial for both native and EFL learners to maintain offline and online communication in the globe. Bangladesh is in an EFL context where Bangla is used in all spheres of life by $98 \%$ population of the country[1]. For preparing Bangladeshi learn- 
ers to cope up with the globalization demands, the English language is a compulsory part of the curriculum in primary, secondary, and higher secondary level [2]. The medium of instruction of language in higher education is in English. For official activities, almost in all the sectors, English is used alongside Bangla. Thus, oral English communication skills (OECSs) from academic to a professional career is very crucial for learners.

Moreover, the present world is witnessing a fourth industrial revolution in which technology makes the space and distance of the world smaller because of quick and sharp communication. In this era of the fourth industrial revolution, only English is such a language accepted globally. And oral English communication skills play a vital role in this communication.

Nonetheless, the standard of the oral skill of Bangladeshi learners is not up to the mark [3]. Even learners who completed his/her graduation do not have a standard level of oral skills. Furthermore, the level of English proficiency of Bangladeshi is fallen within the very low proficient countries[4]. Thus, it is a need to investigate the problems that are responsible for learners' poor oral English communication skills and find out the appropriate solution for dealing these problems for developing learners' oral English communication skills at tertiary level in Bangladesh.

On the other hand, the generations of the era of the fourth industrial revolution were "born with smartphones" and are very familiar with the different features of these technologies [5]. Consequently, the use of the smartphone has been rocketing as the most used hand-held device in Bangladesh. The report shows that there are 164.832 million active mobile users and 99.059 million active internet users[6] of about 168.1 million people in Bangladesh [7]. Additionally, the government of Bangladesh has commenced a master plan (2012-2021) at all the levels of education for the use of ICT creating opportunities for education to all, improvement of the standard education, producing skilled workforce, and eradication of digital divide/discrimination for keeping the pace with fourth industrial revolution. For gaining these goals, the objectives of this master plan are to advance teaching and learning environment, teachers' professional and ICT skills and standardizing teachinglearning materials, building up skilled human resources as per needs of the present time [8]. Consequently, policymakers, teachers and educators are trying to integrate technologies, especially smartphones, to teach language skills of the tertiary level learners in Bangladesh.

Nonetheless, before the adoption of smartphone technologies for teaching and learning languages kills effectively, the learners' readiness should be investigated. At the same times, the investigation should be done for identifying the problems learners faced while learning oral skills for developing their skills in this regards. Therefore, the objectives of this study are to investigate the EFL learners' level of readiness to use a smartphone and the problems they faced during learning oral communication skills at the tertiary level in Bangladesh. Moreover, this study would promote to offering insights for teachers and education policymakers to rethink the actual problems learners faced and their readiness to implement smartphone inside and outside the classroom for developing oral English communication skills. This study also would offer scope to implement smartphones for dealing with learners' problems for devel- 
oping oral English communication skills in any EFL contexts as well as in the Bangladeshi context.

\section{$2 \quad$ Literature Review}

\subsection{Adoption of the smartphone in the language learning process}

Because of the nature of multiple functions of smartphones along with portability, accessibility, immediacy, permanency, connectivity and ubiquity, the adoption of smartphone in the field of language skills teaching and learning is getting effective and popularized in many EFL contexts in the globe [9]. Moreover, smartphones are extensively used for dealing with information on education and provide entertainment at home and institutes [10]. Both teachers and learners are accustomed to using a smartphone in their everyday life. Using smartphones into learning language skills process from both sides of teachers and learners are useful [11]. Further, the use of smartphones and their apps create positive effects on learners' motivation to learn English as a foreign language [12]. The apps of smartphone-like WhatsApp, YouTube, Facebook, SMS, MMS etc. have a significant impact on language skills learning process [13]. Teachers are using smartphones for accessing teaching materials or supporting information. Learners are using smartphones as learning aids for comprehensive learning experiences, multi-sources and multitask, and interacting with teachers outside classes to manage their group assignments. However, assimilating smartphones in a classroom-teaching environment is a challenging task [14]. For mitigating challenges to integrating smartphone for the learning process, learners' readiness should be investigated at tertiary level education in the context of Bangladesh [15].

\subsection{Learners' readiness to use a smartphone in global contexts}

For adopting smartphones effectively in the classroom for learning and teaching language skills, exploring learners' readiness of using smartphone should be elicited. Thus, the studies on soliciting tertiary EFL learners' readiness of the adoption of smartphone for learning language skills have increasingly investigated in many global EFL contexts, like Pakistan, Nigeria, Malaysia, Myanmar, Algeria [16]-[22]. These studies have investigated the readiness of EFL learners from primary to higher education level to adopt mobile technologies for learning English language skills. For example, in Pakistan, a study conducted through a survey questionnaire to explore university learners' readiness to use a mobile device for facilitating educational activities. The results have shown that students had a high level of readiness to use a mobile device for learning purpose [16].

Again, in the Nigerian context, a quantitative study was conducted, and the results have explained learners' readiness in terms of performance expectancy, effort expectancy, social influence, and mobile learning conditions for using mobile devices at tertiary level [17]. Similarly, in Malaysia, a quantitative study carried out among ter- 
tiary level learners to explore the readiness of using mobile devices in higher education at a public university. The study reported that learners had a significant level of readiness categorizing as basic readiness, skills readiness, psychological readiness, and budget readiness [23].

Additionally, a quantitative study conducted among university students in the contexts of Gulf Cooperative country (GCC), e.g. Saudi Arabia, Kuwait, the United Arab Emirates, Qatar, Bahrain, and Oman and found that learners were ready to adopt mobile phone for learning purposes [21].

The literature mentioned above showed a significant level of learners' readiness to use a smartphone for learning purposes at tertiary level. But there is a scarcity of research investigating learners' readiness of using a smartphone to deal with the problems EFL learners faced while learning oral English communication skills. Moreover, there is also a scarcity of evidence in the literature to explore learners' readiness of using a smartphone to learn oral English communication skills at tertiary level in Bangladesh. Thus, this study has conducted for bridging these research insights into exploration.

\subsection{EFL learners' problems in EFL contexts}

Oral communication skill is one of the most critical aspects of learning English as a native (L1) or foreign (FL) or second language (L2). The body of literature on investigating tertiary level EFL learners' problems for learning oral skill is gradually increasing in the EFL contexts for developing learners' oral skills. The previous studies reported EFL learners faced numerous problems in different EFL contexts, e.g. in China, Jordan, Malaysia, Japan, Palestine, Ukraine and Iran while learning oral English communication skills [24]-[30].

The significant problems EFL tertiary level learners faced during oral skills learning were the use of mother tongue, large size class and insufficient class time. These problems were the major causes of EFL learners' low proficiency in oral skill in the context of Jordan [25]. In the alien of these problems, a quantitative study reported that autonomous ability, choosing the proper words and oral English learning environment were the difficulties for learning Chinese EFL learners' oral English communication skills [31]. This result echoed in the Malaysian context adding the lack of linguistic knowledge of EFL learners caused their poor oral performance in a study of mixed-method approach [30].

Besides, in the Japanese context, lack of oral practice environment and teachers' efficacy was the significant difficulties for Japanese university learners' learning oral communication skills [29]. The study in the Ukrainian context added psychological problems, inappropriate teaching methods, curricula and textbooks were the other issues for tertiary-level learners' oral communication skills learning [28]. In addition to these problems, a review study reported the examination system of EFL contexts was also responsible for EFL learners' poor oral skills [32].

However, for investigating the problems of tertiary-level EFL learners for learning OECs, a limited number of studies was found in recent years in Bangladesh. As a study conducted with a mixed-method approach for exploring EFL learners' problems 
for learning OECSs at a university, and the problems were reported regarding merely linguistic, psychological and teachers' efficacy [33]. Thus, more studies are needed to explore the problems of tertiary-level EFL learners' OECSs learning in Bangladesh.

From the literature, as mentioned above, the researchers found several problems, e.g. large size class, limited time for class, lack of oral practice environment, linguistic and psychological issues that EFL learners faced during learning OECSs in different EFL contexts. Thus, for facilitating oral English communication skills teaching and learning at the tertiary level in Bangladesh, this study would explore the problems of EFL learners faced during their OECSs learning.

\section{$3 \quad$ Research Objectives}

The objectives of this study were to investigate EFL learners' readiness of using a smartphone and the problems they faced during learning oral English communication skills at tertiary level in Bangladesh.

\section{$4 \quad$ Method}

For investigating EFL learners' readiness of using a smartphone and the problems, faced during learning oral English communication skills at tertiary level in Bangladesh, an explanatory sequential mixed-method research design was employed using quantitative and qualitative data in this study. According to the explanatory sequential mixed method design, this study began with a quantitative approach and ended with a qualitative approach where quantitative was more emphasized than qualitative to investigate the research objectives [34]. In this study, researchers used a survey questionnaire and semi-structured interview for collecting data to gain the research objectives.

\subsection{Participants' demographic profile}

The participants of this study were a sample of sixty-one $(n=61)$ Bangladeshi EFL learners ( 2 sections) in the first year of their Bachelor's degree (i.e. undergraduate) from a private university in Sylhet, Bangladesh. Participants' native language was Bengali, and they were studying English as a foreign language. All the participants of the study had at least 12 years of learning English experience from their primary level to the tertiary level education. Out of the 61 participants, 36 were female $(57.4 \%)$ and 26 were male $(42.6 \%)$ who were studying in the program of Bachelor of Arts (B.A.) in English at the department of English of that university. The average age of the students was about 17.40. All the participants were selected using a simple random sampling technique from 85 students who were studying at 1 st year 1 st and 2 nd semester of the department. The participants were chosen because they did not have any experience to use smartphone into their class and were studying two courses related to oral English communication skills. 


\subsection{Data collection process}

For soliciting EFL learners' readiness of using a smartphone and the problems for learning OECSs, both quantitative (survey) and qualitative (semi-structured interview) data collection instruments were applied. After collecting and analyzing quantitative data, the qualitative data collected and analyzed for elaborating quantitative findings.

A survey design consisted of a set of 23 items of the questionnaire was adapted from the previous literature [35]-[37]. The questionnaire was divided into two sections: section one was learners' readiness comprises 11 items adapted from [35] and [36], and section two was learners' problem consists of 12 items was adapted from [37]. The items of both sections followed five-point Likert-scale as Strongly Disagree=1; Disagree=2; Neutral=3; Agree=4; Strongly Agree=5. At the beginning of the questionnaire, there was demographic information of the participants, like $1=$ male, $2=$ female; $1=$ first semester, and $2=$ second semester.

Notably, before collecting data, a pilot test was conducted to check the validity and reliability of the items. Additionally, the set of questionnaires was sent to three English language-teaching experts with similar backgrounds, and they were asked to read. The experts' opinions were taken and modified the survey accordingly. This step aided adjusting the confusing language and the deletion of redundant items. After that, this set of questionnaires was distributed among 85 learners, and 61 learners voluntarily participated and responded. For the reliability of the final questionnaire, the Cronbach's alpha values are presented in Table 1. The table shows the value of Cronbach's alpha coefficients for both variables exceeded the minimum level of 0.70 [38]. The values of Cronbach's alpha showed that the items of the questionnaire had good interrater reliability. It also assisted in ensuring the appropriateness of the items in the questionnaire to determine the research objectives, and that the content was comprehensible to learners.

Table 1. Cronbach Alpha Coefficients

\begin{tabular}{|l|c|}
\hline \multicolumn{1}{|c|}{ Variables } & Cronbach's Alpha \\
\hline Learners' readiness & 0.718 \\
\hline Learners' Problems & 0.781 \\
\hline
\end{tabular}

On the other hand, the interview conducted choosing participants purposefully until the saturation point. After interviewing the four learners, the saturation point emerged. Among the four participants, three was males, and the remaining one was female. The interview lasted around 15 to 20 minutes.

\section{$5 \quad$ Data Analysis Process}

Both quantitative and qualitative data were processed and analyzed quantitatively and qualitatively, using different software. The Statistical Package for the Social Sciences (SPSS) Version 25 was used for processing and analyzing quantitative data. 
The two research questions for this study were investigated by using descriptive statistics for the quantitative data. The qualitative data were transcribed and imported into NVIVO 12 for coding and sub coding for emerging themes. Three themes, such as availability, usability and positivity for the readiness of using a smartphone, were emerged. And four themes such as large size class, lack of oral practice environment, authentic materials and use of mother tongue as the problems for learning OECSs extracted for elaborating and creating an in-depth understanding of the results from the quantitative analysis. The findings are presented below in the aligned with the guiding questions of the study.

\section{$6 \quad$ Quantitative Findings}

\subsection{Learners' level of readiness to use the smartphone}

For soliciting learners' level of readiness for using a smartphone, the frequency and percentage of the five Likert scales are presented in Table 2 after calculating descriptive statistics with SPSS 25.0. The table shows that the total number of responses is $671(100 \%)$ earned from the 61 respondents' reply to the 11 questions of this part of the study. The findings presented intensity of learners' individual level on the readiness scales where 'Strongly Agree' and 'Agree' are more frequent than "Disagree" and "strongly Disagree". According to the findings, learners had a high level of readiness as most of the participants agreed $(80.47 \%)$ to use a smartphone for learning and developing oral English communication skills at tertiary level in Bangladesh. Very few participants $(5.96 \%)$ were dubious about using a smartphone in this regard. The findings revealed that learners had a positive attitude for the adaptation of smartphones for learning oral English communication skills at tertiary level.

Table 2. Frequency of Learners' readiness to use the smartphone

\begin{tabular}{|l|l|c|c|c|c|}
\hline \multicolumn{7}{|c|}{ Learners' readiness } \\
\hline \multirow{3}{*}{ Valid } & Frequency & Percentage & Valid Percentage & Cumulative Percentage \\
\cline { 2 - 6 } & Strongly Disagree & 66 & 9.83 & 9.83 & 9.83 \\
\cline { 2 - 6 } & Disagree & 25 & 3.73 & 3.73 & 13.56 \\
\cline { 2 - 6 } & Neutral & 40 & 5.96 & 5.96 & 19.52 \\
\cline { 2 - 6 } & Agree & 89 & 13.26 & 13.26 & 32.78 \\
\cline { 2 - 6 } & Strongly Agree & 451 & 67.21 & 67.21 & 100 \\
\cline { 2 - 6 } & Total & 671 & 100 & 100 & \\
\hline
\end{tabular}

Descriptive analysis is also conducted for "mean" and "standard deviation" of individual items for soliciting learners' readiness presented in Table 3. Considering 'Neutral' as a midpoint of 3, the mean value higher than three (3) are measured that learners had a high level of readiness indicated that EFL learners were ready to use a smartphone for learning oral English communication skills at tertiary level in Bangladesh. Opposingly, the mean value of an item below 3 indicated that there was a low level of readiness of participants in this study. 
Table 3. Learners' readiness item scales analysis

\begin{tabular}{|c|l|c|c|l|}
\hline \multicolumn{2}{|c|}{ Items (Overall Mean=4.27) } & Mean & $\begin{array}{c}\text { Standard } \\
\text { Deviation }\end{array}$ & $\begin{array}{l}\text { Level of } \\
\text { Readiness }\end{array}$ \\
\hline 1. & $\begin{array}{l}\text { I am skilled to use the features of smartphone (Android/iOS) for } \\
\text { learning purpose }\end{array}$ & 4.81 & 0.62 & High \\
\hline 2. & I frequently access into internet at home and university & 4.75 & 0.65 & High \\
\hline 3. & $\begin{array}{l}\text { I can use educational apps (e.g. dictionary) through smartphone } \\
\text { for learning purpose }\end{array}$ & 4.59 & 1.04 & High \\
\hline 4. & $\begin{array}{l}\text { I can use social apps (e.g. FB messenger/ WhatsApp) through } \\
\text { smartphone for connecting with teachers and classmates. }\end{array}$ & 4.52 & 1.15 & High \\
\hline 5. & $\begin{array}{l}\text { I can take help for learning materials from online (e.g. } \\
\text { google/YouTube) through smartphone. }\end{array}$ & 4.41 & 1.17 & High \\
\hline 6. & $\begin{array}{l}\text { I can use audio recorder for recording teachers' lectures with } \\
\text { smartphone }\end{array}$ & 1.79 & 1.31 & LOW \\
\hline 7. & $\begin{array}{l}\text { I think I can use the features of smartphone for learning oral } \\
\text { English communication skills }\end{array}$ & 4.42 & .85 & High \\
\hline 8. & I can use smartphone for practicing OECs outside the classroom & 3.72 & 1.34 & High \\
\hline 9. & $\begin{array}{l}\text { My classrooms have wi-fi facilities } \\
\text { In }\end{array}$ & 4.75 & .65 & High \\
\hline 10. & $\begin{array}{l}\text { The features of smartphone can reduce lack of authentic materials } \\
\text { for oral English communication skills }\end{array}$ & 4.30 & 1.09 & High \\
\hline 11. & $\begin{array}{l}\text { The smartphone can be useful learning tools for developing oral } \\
\text { English communication skills. }\end{array}$ & 4.59 & 1.04 & High \\
\hline
\end{tabular}

The findings showed that learners had a steady high level of readiness of using a smartphone as all the mean values of the items were upper than midpoint value 3.00 except item no. 6 (1.79). The results showed that the highest level of readiness was found for using smartphone (4.81), internet (4.75) and wi-fi connection in the classroom (4.75). The results also showed that learners had a high level of readiness for using educational apps (4.59), social apps (4.52), Google (4.41), and YouTube (4.42) for learning oral English communication skills. Furthermore, the findings displayed that learners were connected with their teachers through social networking (3.75), and they agreed the features of the smartphone could reduce the lack of learning materials (4.30) and be a useful learning tool (4.59) for oral English communication skills. Conversely, the lowest mean value of item no. 6 indicated that learners did not use their smartphone for recording teachers' lectures in the classroom.

However, the overall mean value (4.24), which is far above the neutral point indicated that participants were found to have a high level in terms of adopting smartphone for OECSs learning.

\subsection{EFL learners' problems}

For soliciting learners' problems, the learners faced while learning OECSs, the frequency and percentage of the five Likert scales presented in Table 4 after calculating descriptive statistics with SPSS 25.0. The total number of responses is $732(100 \%)$ ensued from the 61 respondents' reply to the 12 questionnaires of this study. The findings showed that learners had encountered different problems while learning OECSs as the majority of participants $(80.05 \%)$ concerned with "Agree" and "Strongly 
Agree". Only a few learners $(10.24 \%)$ did not face any problems, and some few other $(9.70 \%)$ did not understand whether they had problems or not. However, the findings showed learners had some definite problems.

Table 4. Frequency of Learners' problems

\begin{tabular}{|l|l|c|c|c|c|}
\hline Valid & Frequency & Percentage & Valid Percentage & Cumulative Percentage \\
\cline { 2 - 6 } & Strongly Disagree & 40 & 5.46 & 5.46 & 5.46 \\
\cline { 2 - 6 } & Disagree & 35 & 4.78 & 4.78 & 10.24 \\
\cline { 2 - 6 } & Neutral & 71 & 9.70 & 9.70 & 19.94 \\
\cline { 2 - 6 } Agree & 127 & 17.35 & 17.35 & 37.29 \\
\cline { 2 - 6 } & Strongly Agree & 459 & 62.70 & 62.70 & 100 \\
\cline { 2 - 6 } & Total & 732 & 100 & 100 & \\
\hline
\end{tabular}

Descriptive analysis was also conducted for "mean" and "standard deviation" of individual items for soliciting learners' the problems they faced during learning OECS. By using 'Neutral' as a midpoint of 3, the mean value higher than three (3) is considered that respondents had several problems while they were learning oral English communication skills through existing teaching method at tertiary level in Bangladesh.

Table 5. Learners' Problems Items Scales Analysis

\begin{tabular}{|c|l|c|c|c|}
\hline \multicolumn{2}{|c|}{ Items (Overall Mean=4.27) } & Mean & $\begin{array}{l}\text { Standard } \\
\text { Deviation }\end{array}$ & Rank \\
\hline 1. & $\begin{array}{l}\text { I think there is lack of authentic materials for oral English communication } \\
\text { skills learning }\end{array}$ & 4.75 & 0.65 & 2 \\
\hline $\begin{array}{l}\text { 2. } \\
\text { There is inconsistency in syllabus for learning oral English communication } \\
\text { skills }\end{array}$ & 4.60 & 1.04 & 3 \\
\hline 3. & $\begin{array}{l}\text { There is lack of oral English communication skills learning activities in } \\
\text { traditional teaching method }\end{array}$ & 4.54 & 0.56 & 5 \\
\hline 4. & $\begin{array}{l}\text { Learning oral English communication skills is difficult because of large } \\
\text { size class }\end{array}$ & 4.59 & 1.04 & 4 \\
\hline 5. & My university has lack of language lab or studio & 4.23 & 0.53 & 6 \\
\hline 6. & My classroom has lack of multimedia facilities & 4.18 & 0.87 & 7 \\
\hline 7. & There is lack of oral practice environment outside the classroom & 4.59 & 1.04 & 4 \\
\hline 8. & I seldom speak in English with my teachers in the class & 3.23 & 1.31 & 8 \\
\hline 9. & I seldom speak in English with my friends outside the class & 2.44 & 1.23 & 9 \\
\hline 10. & Students need audio-visual aids to learn oral English communication skills & 4.59 & 1.04 & 4 \\
\hline 11. & $\begin{array}{l}\text { The exiting teaching method is unsupportive for learning oral English } \\
\text { communication skills }\end{array}$ & 4.59 & 1.04 & 4 \\
\hline 12. & $\begin{array}{l}\text { If I could get opportunity to practice, I could develop my oral English } \\
\text { communication skills }\end{array}$ & 4.92 & .33 & 1 \\
\hline
\end{tabular}

According to the findings, the most problems the learners faced were lack of authentic materials $(m=4.75)$ and inconsistent syllabus $(m=4.60)$. The other significant problems the learners faced were lack of oral practice environment $(\mathrm{m}=4.59)$, large size class $(\mathrm{m}=4.59)$, lack of audio-visual aids $(\mathrm{m}=4.59)$ and existing teaching method $(m=4.59)$ while learning OECSs. Again, lack of oral learning activities $(m=4.54)$ was 
also a big problem for learning OECSs. The findings also showed that learners rarely spoke in English with teachers $(\mathrm{m}=3.23)$ in the class. But they sometimes spoke English with other classmates outside the class $(m=2.44)$. From the findings learners also faced the problems as the university had lack of multimedia $(m=4.23)$ and lab facilities $(\mathrm{m}=4.18)$. Nonetheless, most of the learners agreed that if they availed an opportunity to practice English oral practice $(m=4.92)$, they could develop their oral English communication skills.

However, with an overall mean of 4.27 , which is far above the neutral point indicated that participants encountered problems while learning oral English communication skills at tertiary level in Bangladesh.

\section{$7 \quad$ Qualitative Findings}

After processing and analyzing the quantitative data, participants have expanded on their responses through face to face semi-structured interview sessions on readiness and the problems they faced for learning OECSs. Seven themes emerged from the qualitative portion of the data for smartphone readiness and problems: availability, usability, positivity, psychological, linguistic problems, teachers' efficacy and use of mother tongue.

\subsection{Learners' readiness}

The three themes regarding learners' readiness of the use of smartphone emerged from learners' experience are usability, availability and positivity.

\subsection{Availability}

When learners are asked regarding whether they have a personal smartphone, all the learners replied they were using a smartphone as their individual properties. They were using smartphones from higher secondary level. Three learners reported they were using android version, and the other two replied they were using iOS version.

\subsection{Usability}

Concerning the questions about the purpose of using a smartphone, all learners stated they were using a smartphone for voice calls, SMS and social networking through different apps like Facebook, WhatsApp. They sometimes surfed on various websites for learning materials. One learner told I also use education apps for learning vocabulary. Another learner replied I surf google for learning materials with smartphone. 


\subsection{Positivity}

When learners were asked regarding the use of a smartphone as a learning tool for developing oral English communication skills in the classroom, most of the learners expressed positive attitude. They also reported that it would be exciting if smartphones were included into the classroom activities. They expressed the use of smartphones could create oral practice environment outside the classroom. One learner commented it may create disturbance for the class.

\subsection{Learners' problems}

The four central themes regarding the problems that emerged from learners' experiences on learning oral English communication skills are psychological, linguistic, teachers' efficacy and use of mother tongue.

Psychological problems: Participants reported that they had faced several psychological problems, e.g. hesitation, fear of mistakes and shyness while they were learning OECs at any educational level. One Interviewee said, though I am learning English from primary level and still learning English. But when I try to speak with someone, I feel hesitated. Another Interviewee reported I always have a good grade, but when I speak with others, I am always afraid of my mistakes. The other Interviewee said I couldn't speak because I feel shy.

Linguistic problems: When learners were asked regarding their linguistic problems, they shared their experiences and reported that they had problems in pronunciation, finding words and grammatical mistakes while they were speaking in English. One Interviewee stated I had pronunciation problems when I speak. In addition, another interviewee reported when I speak, I don't find words to speak. And other Interviewee commented I make mistakes grammatically when I communicate orally.

Teachers' efficacy: In response to the question regarding teachers' efficacy in oral communication skills, most of the learners replied that teachers were proficient at that skill. One learner commented. Some teachers are not efficient in speaking. They need to increase their efficacy in this skill.

Use of mother tongue: Regarding the use of language, the majority of the learners noticed that they always spoke in their mother tongue inside and outside the classroom. One learner told They speak in English only when teachers ask them in the classroom. Outside they speak English seldom. The other learner said they need not use English in their practical life. They only talk to Bangla when they communicate with others. The extensive use of mother tongue is one of the significant problems for learning OECSs.

\section{Discussion}

The present study examines to solicit the level of learners' readiness for using smartphones and the problems they faced while learning OECSs at the tertiary level. Results from questionnaires and semi-structured interview indicated that learners had 
a high level of readiness for using a smartphone to learn OECSs and several problems during learning OECSs. Moreover, learners showed their interest in using different features of smartphone for learning OECSs inside and outside the classroom.

\subsection{Learners' level of readiness to use the smartphone}

The results illustrated that EFL learners who participated in the questionnaire had a high level of readiness to use a smartphone for oral skill learning. The respondents of this study who were tertiary level learners used a smartphone, either it was android or iOS version. They also used educational apps like a dictionary, social apps like Facebook, Messenger and WhatsApp using the internet at home and university campus. In the university, their classrooms were wi-fi connected. Moreover, they believed that smartphone could be a useful learning tool to minimize the lack of oral skill learning resources. The results from the semi-structured interview reported that readiness was defined by the themes availability, usability and positivity of the use of smartphone for learning language skills purpose. These findings were supported by the studies [17], [18], [20], [21], [23] where learners' readiness reported as high level.

Similar results were reported in the study of the context of Myanmar [22] where the readiness of tertiary-level learners to use a smartphone in sharing photo/video, accessing webpages, downloading files, sending/receiving emails and messages, and accessing social sites was high. The qualitative results were aligned with the study of the context of Pakistan, where tertiary EFL learners' level of readiness defined by the terms, availability, accessibility and affordability [16]. Thus, the findings of this study suggested that Bangladeshi tertiary EFL learners had a high level of readiness of using the features of a smartphone for learning oral communication skills.

\subsection{EFL learners' problems}

The results demonstrated that EFL learners who participated in the questionnaire agreed that there were several problems like authentic materials, inconsistent syllabus, lack of oral activities, large size class, oral practice environment, lack of audio-visual aids and existing teaching method for learning oral English communication skills at tertiary level in an EFL context like Bangladesh. The results from the semi-structured interview expanded learners' problems related to psychology, linguistics, teachers' efficacy, and the use of the mother tongue. The similar kind of problems was reported in the study of [25], [26], [28]-[30] where these problems made hindrances to learn oral English communication skills. These findings were also aligned with that of [16], that reported problems related to oral practice environment, instructor, the teaching facilities, and the curricula of the education system of the country for Iranian tertiary level learners to learn oral skills. A similar result was reported in the study of [27] pointing the problems related to oral practice environment, English teachers, teaching resources, materials and curriculum were responsible for the poor oral performance of Chinese tertiary level EFL learners.

The present study suggested that the problems, as mentioned above, played a negative role to develop EFL learners OECSs at tertiary level in Bangladesh. To prepare 
tertiary level learners as conversant in OECSs, educators and teachers need much attention to address these problems.

Therefore, the findings from both quantitative and qualitative data would open a window for researchers to integrate smartphones in the classroom for dealing with the problems to develop oral skills of tertiary level learners in Bangladesh. These findings could also be implemented for making a comparison with other department or solely English department of the universities in Bangladesh or any different EFL contexts.

\section{Conclusion}

The objectives of the present study are to investigate EFL learners' readiness of using a smartphone and the problems they faced during learning oral English communication skills at tertiary level in Bangladesh. The findings of this study from the questionnaire suggested that EFL learners had a high level of readiness to use a smartphone for learning oral English communication skills. And the most frequent problems faced by Bangladeshi learners were related to authentic materials, audiovideo aids, oral practice environment, large size class and existing teaching method. The findings of semi-structured interviewed suggested that learners' readiness was categorized as availability, usability and positivity for the use of smartphone for learning oral English communication skills. Whereas, EFL learners' problems were related to psychological, linguistic, teachers' efficacy and use of mother tongue for learning OECSs.

\section{Limitations}

The limitations of this study are the following:

- First, the study is limited to only one department (English) in the university. This study does not allow for comparison between departments, so the results cannot be generalized

- The second limitation is the sample population size. This study only employed only 61 students of $1^{\text {st }}$ year $1^{\text {st }}$ and $2^{\text {nd }}$ semester as participants. The small number of participants can enact limitations on the generalizations of results.

- Last but not the least limitation of this study is that this study only deals with learners' perceptions of their readiness and the problems they faced while learning oral English communication skills at tertiary level.

\section{Recommendations for Future Studies}

The purpose of the current study is to offer a comprehensive view of learners' readiness to use a smartphone and the problems they faced during learning OECSS at higher education in Bangladesh. Further research could investigate the impact of using smartphones for dealing with the problems like lack of oral practice environment, 
large size class, lack of oral learning activities and lack of authentic materials learners faced for learning OECSs in an EFL context. Moreover, more than one department or university could be engaged in the data collection to increase the reliability of the study. More research is also recommended to explore the use of different features of smartphones like WhatsApp, YouTube, voice recorder, a video camera for providing learners oral practice environment inside and outside the classroom for developing EFL learners' oral English communication skills. Besides, further research could be done to investigate the correlation between learners' readiness and problems. Finally, a similar study could be held in another context with another level of learners. More research needs to be conducted on the implementation of smartphone for learning other language skills such as writing, listening and reading.

\section{References}

[1] S. Rumnaz Imam, "English as a global language and the question of nation-building education in Bangladesh," Comp. Educ., vol. 41, no. 4, pp. 471-486, Nov. 2005. https://doi.org/ $10.1080 / 03050060500317588$

[2] M. Rasheed, "Learning English language in Bangladesh: CLT and beyond," Crit. Lit. Theor. Pract., vol. 6, no. 2, pp. 31-49, 2012.

[3] Z. Rahman, A. F. M. M. Rahman, and M. K. Begum, "Enhancement of students' English speaking in Bangladesh : theory and practices," Manarat Int. Univ. Stud., vol. 5, no. 1, pp. 127-136, 2015.

[4] E. EPI, "EF English Proficiency Index," 2019.

[5] S. Papadakis, M. Kalogiannakis, E. Sifaki, and N. Vidakis, "Access moodle using smart mobile phones. A case study in a greek university," Lect. Notes Inst. Comput. Sci. Soc. Telecommun. Eng. LNICST, vol. 229, pp. 376-385, 2018. https://doi.org/10.1007/978-3-3 19-76908-0_36

[6] B. T. R. Commission, "Mobile Phone Subscribers in Bangladesh November, 2019 Mobile," Ministry of Post, Telecommunication \& Information Technology, Bangladesh, 2019. [Online]. Available: http://www.btrc.gov.bd/content/mobile-phone-subscribers-bangladesh -november-2019. https://doi.org/10.1787/oif-2008-graph3-en

[7] U. N. P. F. (UNFPA), "Bangladesh - Overview," 2019.

[8] M. of Education, "Master Plan for ICTE 2012-20121 (Government of the People's Republic of Bangladesh," 2013.

[9] R. Darmi and P. Albion, "Enhancing Oral Communication Skills Using Mobile Phones Among Undergraduate English Language Learners in Malaysia," in Mobile Learning in Higher Education in the Asia- Pacific Region, Education, vol. 40, 2017, pp. 359-375. https ://doi.org/10.1007/978-981-10-4944-6_15

[10] S. Papadakis, N. Zaranis, and M. Kalogiannakis, "Parental involvement and attitudes towards young Greek children's mobile usage," Int. J. Child-Computer Interact., vol. 22, no. xxxx, p. 100144, 2019. https://doi.org/10.1016/j.ijcci.2019.100144

[11] J. Eppard, Z. Hojeij, P. Ozdemir-Ayber, M. Rodjan-Helder, and S. Baroudi, "Using mobile learning tools in higher education: A UAE Case," Int. J. Interact. Mob. Technol., vol. 13, no. 11, pp. 51-69, 2019. https://doi.org/10.3991/ijim.v13i11.10823

[12] B. Klímová, "Mobile phones and / or smartphones and their apps for teaching English as a foreign language," Educ Inf Technol, 2017. https://doi.org/10.1007/s10639-017-9655-5 
[13] E. N. Mustafa and Elhadi, "The Impact of YouTube, Skype and WhatsApp in improving EFL Learners' Speaking Skill," Int. J. Contemp. Appl. Res., vol. 5, no. 5, pp. 18-31, 2018.

[14] M. Anshari, M. N. Almunawar, M. Shahrill, D. K. Wicaksono, and M. Huda, "Smartphones usage in the classrooms: Learning aid or interference?," Educ. Inf. Technol., vol. 22, no. 6, pp. 3063-3079, 2017. https://doi.org/10.1007/s10639-017-9572-7

[15] K. M. A. Islam, "Usage of mobile phones in the English language class- rooms of Bangladesh : new perspectives," Green Univ. Rev. Soc. Sci., vol. 3, no. 2, 2017.

[16] M. Bakhsh, A. Mahmood, and N. A. Sangi, "An assessment of students' readiness towards mobile learning at AIOU, Pakistan," 2015 Int. Conf. Inf. Commun. Technol. ICICT 2015, pp. 1-6, 2016. https://doi.org/10.1109/icict.2015.7469579

[17] J. G. Chaka and I. Govender, "Students' perceptions and readiness towards mobile learning in colleges of education: A Nigerian perspective," South African J. Educ., vol. 37, no. 1, pp. 1-12, 2017. https://doi.org/10.15700/saje.v37n1a1282

[18] A. Miglani and A. K. Awadhiya, "Mobile Learning: Readiness and Perceptions of Teachers of Open Universities of Commonwealth Asia.," J. Learn. Dev., vol. 4, no. 1, pp. 58-71, 2017.

[19] B. M. Mizad, Z. A. Sayadi, and S. L. Sukiman, "Students Readiness and Motivation to Use Mobile Phone for Learning English at Higher Learning Institution," Int. J. Asian Soc. Sci., vol. 8, no. 11, pp. 1077-1087, 2018. https://doi.org/10.18488/journal.1.2018.811.1077.108 $\underline{7}$

[20] K. Saidouni and A. Bahloul, "The Use of Mobile -Assisted Language Learning in EFL Teaching and Learning: Practices and Readiness," Trans Internet J. Cult. Stud., vol. 22, 2018. https://doi.org/10.35553/1699-000-021-030

[21] M. Shorfuzzaman and M. Alhussein, "Modeling Learners' Readiness to Adopt Mobile Learning: A Perspective from a GCC Higher Education Institution," Mob. Inf. Syst., vol. 2016, 2016. https://doi.org/10.1155/2016/6982824

[22] M. M. The and T. Usagawa, "Investigation of students' mobile phone usage and influences towards their mobile learning adoption: A case study in Myanmar," Int. J. Interact. Mob. Technol., vol. 12, no. 5, pp. 43-57, 2018. https://doi.org/10.3991/ijim.v12i5.8924

[23] M. Mizad, Z. S. Yusoff, Z. A. Sayadi, A. A. Latif, and S. L. Sukiman, "Students Readiness and Motivation to Use Mobile Phone for Learning English at Higher Learning Institution," Int. J. Asian Soc. Sci., vol. 8, no. 11, pp. 1077-1087, 2018. https://doi.org/10.18488/jour nal.1.2018.811.1077.1087

[24] A. Asakereh and H. S. Afshar, "Speaking skills problems encountered by Iranian EFL freshmen and seniors from their own and their english instructors' perspectives," Electron. J. Foreign Lang. Teach., vol. 13, no. 1, pp. 112-130, 2016.

[25] D. A. Al-Jamal and G. A. Al-Jamal, "An investigation of the difficulties faced by EFL undergraduates in speaking skills," English Lang. Teach., vol. 7, no. 1, pp. 19-27, 2013. https ://doi.org/10.5539/elt.v7n1p19

[26] A. A. Alyan, "Oral Communication Problems Encountering English Major Students: Perspectives of Learners and Teachers in Palestinian EFL University Context," Arab World English J., vol. 4, no. 2, pp. 160-172, 2013.

[27] Z. Liu, "Factors affecting english listening and speaking abilities of non-english major students: Taking engineering students as an example," World Trans. Eng. Technol. Educ., vol. 13 , no. 4, pp. 593-597, 2015.

[28] O. Polishchuk, "Communication Barriers Faced By English Language Learners At a University Level: Factors and Solutions," Sci. Educ., vol. 23, no. 8, pp. 44-48, 2018. 
[29] M. Yanagi and A. A. Baker, "Challenges Experienced by Japanese Students With Oral Communication Skills in Australian Universities," TESOL J., vol. 7, no. 3, pp. 621-644, 2016. https://doi.org/10.1002/tesj.229

[30] N. Zukurnain and S. Kaur, "Oral English Communication Difficulties and Coping Strategies of Diploma of Hotel Management Students at UiTM," Southeast Asian J. English Lang. Stud., vol. 20, no. 3, pp. 93-112, 2014. https://doi.org/10.17576/31-2014-2003-08

[31] Y. Wei and L. Zhang, "The survey on barriers of oral English learning for college students in China," English Lang. Teach., vol. 6, no. 6, pp. 68-76, 2013.

[32] X. Ibna Seraj, P. M., Habil Hadina and Fu, "EFL Learners' Problems in Learning Speaking Skills in Different Contexts: A study of Literature Review from 2013 to 2018," in 2nd LANGUAGE AND COMMUNICATION POSTGRADUATE INTERNATIONAL SEMINAR (LCPIS) PROCEEDINGS, 2019, pp. 11-13.

[33] K. B. Tushar, "Developing English Speaking Skills of the Students of BRAC University: Problems and Solution," ENH Community J., vol. 1, no. 1, p. 11, 2018.

[34] J. W. Creswel and J. D. Creswell, Research Design Qualitative, Quantitative, and Mixed Methods Approaches. SAGE Publications, Inc., 2018.

[35] S. Almutairy, T. Davies, and Y. Dimitriadi, "The readiness of applying M-learning among Saudi Arabian students at higher education," Int. J. Interact. Mob. Technol., vol. 9, no. 3, pp. 33-36, 2015. https://doi.org/10.3991/ijim.v9i3.4423

[36] B. I. Ismail, S. N. Azizan, and N. Azman, "Teaching via mobile phone: A case study on Malaysian teachers' technology acceptance and readiness," J. Educ. Online, vol. 10, no. 1, 2013. https://doi.org/10.9743/jeo.2013.1.3

[37] A. Afshar, H. S. and Asakereh, "Speaking skills problems encountered by Iranian EFL freshmen and seniors from their own and their english instructors' perspectives," Electron. J. Foreign Lang. Teach., vol. 13, no. 1, pp. 112-130, 2016.

[38] J. M. Cortina, "What is Coefficient alpha? an examination of Theory and Applications," J. Appl. Psychol., vol. 78, no. No 1, pp. 98-104, 1993.

\section{Authors}

Prodhan Mahbub Ibna Seraj is a PhD candidate in Teaching English as Second Language(TESL) at the school of Education,Universiti Teknologi Malaysia(UTM) Mail : mahbub@graduate.utm.my

Dr Hadina Habil is an Associate Professor at Language Academy,Universiti Teknologi Malaysia (UTM). She is currently attached at the Office of Corporate Affairs UTM, managing Media and corporate communication. Contact :https://people. utm.my/hadina/

Dr Md. Kamrul Hasan is working as an Associate Professor in English and also as a coordinator of English Language Institute at United International University, Dhaka, Bangladesh. Mail:mkamrulhasan77@gmail.com

Article submitted 2020-04-10. Resubmitted 2020-05-22. Final acceptance 2020-05-26. Final version published as submitted by the authors. 